\title{
Evolving Forms of Visualisation for Presenting and Viewing Data
}

\author{
Don Passey \\ Department of Educational Research, Lancaster University, UK
}

\begin{abstract}
Teachers have been 'visualising' ideas or information that emerge from data for a long time. Mark books have provided teachers with 'visual', albeit normally numerical, records of pupil attainment and achievement, which they have used to generate views about progress, trends, or the identification of appropriate learning support, for example. The advent of information and communication technologies (ICT) has brought potential to provide perspectives from data in more visual forms; these visual forms would previously have taken a long time to generate, and would have been unlikely to have been dynamic (that is, updated with regularly changing background data, to offer up-to-date pictures). What differences have been made as a result of this potential? Has it meant that 'visualisation' of forms of presentation have changed, that forms of analyses have been introduced, that reliability and robustness have been more focused on, or that different types of needs have arisen? This paper will explore evolving visualisations of curriculum data, and will conclude that different forms of visualisation are being introduced, but do not necessarily make it easier for the teacher to identify necessary or precise detail (or to consider fundamental statistical questions or specific professional needs).
\end{abstract}

Keywords: Visualisation of data; data management and visual forms; school management systems and presentation of data; viewing data

\section{BACKGROUND}

Visualisation of data is clearly an important aspect for those presented with the need to understand and use data (and this includes teachers). It is also clear that the transfer of presented data to information is likely to be supported through forms of visualisation. Indeed, Tufte (1990) in his classic book entitled 'Envisioning information' explores the many ways in which visualisation can support access to and enhance the meaning of data. Teachers are being encouraged to use visualisation of data, both for subject teaching, and for curriculum management purposes. From a research perspective, the literature concerned with visualising data to support subject

Please use the following format when citing this chapter:

Passey, D., 2009, in IFIP International Federation for Information Processing, Volume 292; Evolution of Information Technology in Educational Management; Eds. Tatnall, A., Visscher, A., Finegan, A., O’Mahony, C., (Boston: Springer), pp. 155-167. 
teaching is more developed than is the literature concerned with visualising data for curriculum management purposes. The Smart Centre in Durham University (2007) is, for example, focusing on projects for "envisioning data and reasoning from evidence"; these to date have focused on subject teaching. The Australian Bureau of Statistics (2007) offers a useful review of the literature concerned with data visualisation to support management practices. However, teacher uses for curriculum and classroom management purposes are not a focus of this review. This paper offers an introductory foray into the field, by exploring forms of visualisation for management purposes that have been, and are becoming, available to teachers.

\section{INTRODUCTION}

For the classroom teacher, data are used fundamentally to consider pupil progress and identification of learning support or teaching approach needs. Although teachers have used mark books to record numerical features for a long time, often to give them ideas of how to judge or assess pupil progress and performance, it does not necessarily follow that numerical forms of data about other aspects of curriculum need (such as the estimation of likely future outcomes, or the assessment of appropriate targets and challenge) are as easy for teachers to view or that they are used in particularly useful or analytical ways. As the government department in England said in a document offering advice about data management to secondary schools in 2002:

"... teachers can often be daunted when presented with vast spreadsheets containing columns of data. A data-rich school only becomes information-rich when that data is systematically collected and passed to staff in easily digestible forms. A school that manages data well has systems that allow key aspects of student performance to be easily identified - and staff with the training and time to draw appropriate conclusions from the data available to them. Prior attainment data and effective monitoring are used to identify strengths and weaknesses, and set challenging, but attainable, targets." (DfES, 2002, p.3)

This document suggested that presentation is important, in that information arising from data needs to be easily identifiable, so that strengths and weaknesses, challenges and targets, can be considered and set. It is clear that teachers, when using mark books, have often been able to identify trends with regard to performance and attainment. However, data relating to estimated likely outcomes (future possible attainments) based on prior attainment, or data relating to added value (gains arising from educational experiences and calculated over particular periods of time) have not been accessible to teachers for the same long periods of time. The identification of trends or even the identification of comparative evidence from these forms of data has not been established in long-term practice. 
Indeed, there is little evidence to indicate that teachers currently being qualified are being given deep or insightful experiences in using data for predictive or indicative purposes, to support or inform their trial or future practice. Teachers do not necessarily have training experiences that offer them attributes to easily 'visualise' key features of data. Indeed, some teachers admit that they do not understand the basis on which data is often presented. In the Kirkup, Sizmar, Sturman and Lewis (2005) report on uses of data in schools, they concluded that:
"The main challenges to the effective use of data for primary schools were reported to be: lack of time, particularly time to update and analyse the data; difficulties in applying data to classroom situations; limitations of data, i.e. that the data collected/recorded was too narrow/academic or did not accommodate individual needs; ICT-related issues, e.g. insufficient resources or restricted access. Challenges to the effective use of data for secondary schools were similar to those experienced by primary schools. However, having sufficient trust in the data was also of concern to secondary schools (some respondents believed either that it was unreliable or arrived too late to be of use). Special schools reported two key challenges to the effective use of data: data systems that do not accommodate the complex needs of individual pupils; insufficient comparable data (year-on-year or with similar schools)." (Kirkup et al., 2005, p.4-5)

This report did not highlight issues of 'visualisation' or the potential of forms of visualisation in addressing some of the issues raised within the study (as had the study for the DfES by Passey, 2002), but it did raise issues concerned with knowing about underlying fundamental statistical practices and processes: reliability; validity; robustness; and sampling dynamics. When concerns about visualisation by teachers are considered, there has been a distinct lack of studies into this aspect of the field. Neither the importance of visualisation, nor the potential of visualisation have been studied in any great depth (although it is true to say that the importance of background statistical processing has been considered and has been reported much more widely). At the same time, however, it is clear that ICT-based school management information systems (MISs) have increasingly been adopted and used by schools, and that a part of that adoption has been the increasing power brought to users by ranges of forms of visualisation.

Visscher (2002), in discussing a framework for studying school performance feedback systems, stated that there were likely to be differences in features across different school performance feedback systems. The features that he identified that could be different in different cases were concerned with extents of: information validity; information reliability; how up-to-date the information is; data relevance; indicators of relative and absolute school performance; trends, relationships and differences over time; standard and tailored information; presentation in accessible and appealing forms; support in using data correctly; time and effort requirements; complexity and clarity; and user support in solving problems. It is clear that these features relate not only to the concerns raised within the DfES report 
(2002) and issues raised in the Kirkup et al. report (2005), but that they also refer to aspects concerned with visualisation and the implications of making data accessible through visual formats. The features identified by Visscher (2002) will be used as a categorisation for discussion of the development of forms of visualisation within school MISs in England.

\section{AN EVOLUTIONARY OVERVIEW}

As the Visscher list of features indicate, there is a need to consider both the importance of visualisation in terms of presentational ease and access, and the importance of being able to 'see' that validity, reliability, and relevance are accounted for and considered. However, ease of presentation might mean that some important points remain hidden and are lost to view. It is clear that ease of presentation in itself is not a simple substitute for knowing about the validity of analytical technique when it comes to the need to identify key points for potential action. As Gray (2002) says:

"Judging schools' performance in 'raw' terms may be seen as inappropriate by researchers. Nonetheless, few schools which find themselves in the top half of any resulting 'league tables' will feel threatened by their use, even whilst acknowledging that they do not in reality give an accurate picture of their performance. They may well have learnt to interpret the evidence to their advantage, whatever the actual position. A well-conducted value-added analysis will challenge at least some of these schools, offering little or no comfort." (Gray, 2002, p.149)

This view indicates some concerns about the different ways of indicating and reporting school performance. However, it is just as clear that important points concerned at the pupil level, with pupil performance and challenge, can be also be missed if presentational features are viewed without sufficient consideration being given to analytical background. As Fitz-Gibbon (2002) says:

"Indicator systems may be used in very damaging fashions. By publishing a small number of indicators, attention is focused just on those indicators, and efforts are often directed not at real change but at getting the indicator in the right direction. Thus, the malign effect of the indicator used in England which schools' examination performances were reported in terms of the percentage of pupils achieving Grade $C$ and above. This led to widespread concentration on students likely get a D to push them over the borderline." (FitzGibbon, 2002, p.36)

Visualisation of numerical data can clearly lead to interpretation at a superficial (or selective) level. As Kirkup et al. (2005) suggested, limitations arise not only at the level of ease of presentation, but also at the level of implementation. If visualisation is leading to superficial or selective analysis, and subsequently superficial implementation, then data are clearly not being supportive at an informative level. In the same report, the authors indicate a 
real potential tension with developments of systems that offer increasing detail, but where the level of reliability, validity and relevance at an individual, group, class, or school level is not made clear to them by the system and visualisation itself:

"Some of the needs of special schools are identical to those of mainstream schools; they need systems that are simple to use and allow the easy input and interpretation of data. However, above all they need systems that allow a much finer level of detailed information to be added and that allow progress to be measured in extremely small steps and that accept and recognise that such progress may not be smooth nor linear." (Kirkup et al, 2005, p.81)

Studies to date, therefore, suggest that there are fundamental questions to ask from a visualisation viewpoint (following the features offered by Visscher). Does visualisation indicate anything about information validity or reliability? Does visualisation indicate anything about how up-to-date the information is? Is anything shown regarding data relevance? Are there indicators of relative and absolute school performance? Does visualisation show trends, relationships and differences over time? Does it present standard and tailored information? Is presentation offered in accessible and appealing forms? Is support offered in using data correctly? Are time and effort requirements considered? How are issues of complexity and clarity addressed? How is user support in solving problems addressed?

\section{CONSIDERING SOME INDICATORS OF EVOLUTION OF DATA VISUALISATION}

Different visual forms were used in the DfES report (2002), which offered advice to schools on uses of curriculum data. In Table 1 the visual items used have been grouped according to form and type (as shown in the second column).

Table 1: Visual forms contained in an advisory document on data management (DfES, 2002)

\begin{tabular}{|l|l|c|}
\hline \multicolumn{1}{|c|}{ Purpose of visual items } & $\begin{array}{c}\text { Graphical or tabular form of } \\
\text { visual item }\end{array}$ & $\begin{array}{c}\text { Page } \\
\text { reference in } \\
\text { document }\end{array}$ \\
\hline $\begin{array}{l}\text { Pupil estimated likely outcomes based on } \\
\text { end of Key Stage prior attainment shown as } \\
\text { a calculated value added line }\end{array}$ & $\begin{array}{l}\text { Graphical form, showing a } \\
\text { single line }\end{array}$ & 14 \\
\hline $\begin{array}{l}\text { Pupil estimated likely outcomes based on } \\
\text { end of Key Stage prior attainment shown as } \\
\text { a calculated value added line, with an } \\
\text { additional challenge line to consider target } \\
\text { setting }\end{array}$ & $\begin{array}{l}\text { Graphical form, showing an } \\
\text { estimation line and an additional } \\
\text { challenge line in another colour }\end{array}$ & 14 \\
\hline $\begin{array}{l}\text { Comparison of school and national } \\
\text { baseline data by attainment level for } \\
\text { English and mathematics }\end{array}$ & $\begin{array}{l}\text { Graphical form, showing colour } \\
\text { and height comparisons }\end{array}$ & 9 \\
\hline
\end{tabular}




\begin{tabular}{|c|c|c|}
\hline $\begin{array}{l}\text { Comparison of school and national } \\
\text { baseline data by year for English }\end{array}$ & $\begin{array}{l}\text { Graphical form, showing colour } \\
\text { and height comparisons }\end{array}$ & 9 \\
\hline $\begin{array}{l}\text { Comparison of school with local authority } \\
\text { and national residuals by gender }\end{array}$ & $\begin{array}{l}\text { Graphical form, with columns } \\
\text { for girls and boys shown in } \\
\text { different colours }\end{array}$ & 24 \\
\hline $\begin{array}{l}\text { Comparison of national probability of } \\
\text { pupils attaining particular average scores at } \\
\text { the end of a Key Stage, being able to attain } \\
\text { at the end of the next Key Stage, with } \\
\text { actual school results in mathematics }\end{array}$ & $\begin{array}{l}\text { Graphical form, with columns } \\
\text { for school actuals and national } \\
\text { probabilities being in different } \\
\text { colours }\end{array}$ & 22 \\
\hline $\begin{array}{l}\text { Comparison of national probability of } \\
\text { pupils attaining different particular average } \\
\text { scores at the end of a Key Stage, being able } \\
\text { to attain at the end of the next Key Stage, } \\
\text { with actual school results in mathematics }\end{array}$ & $\begin{array}{l}\text { Graphical form, with columns } \\
\text { for school actuals and national } \\
\text { probabilities being in different } \\
\text { colours }\end{array}$ & 23 \\
\hline $\begin{array}{l}\text { Comparison of achievement results by } \\
\text { levels and grouped by ethnicity }\end{array}$ & $\begin{array}{l}\text { Graphical form, with columns } \\
\text { shown in a colour }\end{array}$ & 29 \\
\hline $\begin{array}{l}\text { National probability of pupils attaining } \\
\text { particular average scores at the end of a } \\
\text { Key Stage, being able to attain at the end of } \\
\text { the next Key Stage }\end{array}$ & $\begin{array}{l}\text { Graphical form, with columns } \\
\text { shown in colour }\end{array}$ & 22 \\
\hline $\begin{array}{l}\text { Comparison of school with local authority } \\
\text { and national residuals }\end{array}$ & $\begin{array}{l}\text { Graphical form, with columns } \\
\text { shown in colour }\end{array}$ & 24 \\
\hline $\begin{array}{l}\text { Comparison of pupil added value (prior } \\
\text { and current plots) with national median and } \\
\text { quartile lines }\end{array}$ & $\begin{array}{l}\text { Graphical form, with median } \\
\text { and quartile lines in different } \\
\text { colours }\end{array}$ & 20 \\
\hline $\begin{array}{l}\text { Comparison of pupil added value (prior } \\
\text { and current plots) with national median and } \\
\text { quartile lines }\end{array}$ & $\begin{array}{l}\text { Graphical form, with median } \\
\text { and quartile lines in different } \\
\text { colours, and pupils with } \\
\text { different extents of added value } \\
\text { highlighted in different colours }\end{array}$ & 21 \\
\hline $\begin{array}{l}\text { Comparison of pupil added value (prior } \\
\text { and current plots) by gender with national } \\
\text { median and quartile lines }\end{array}$ & $\begin{array}{l}\text { Graphical form, with median } \\
\text { and quartile lines in different } \\
\text { colours }\end{array}$ & 21 \\
\hline $\begin{array}{l}\text { Plotting teacher predictions based on prior } \\
\text { attainment against a previous year trend } \\
\text { line }\end{array}$ & $\begin{array}{l}\text { Graphical form, with pupils with } \\
\text { low estimated added value being } \\
\text { highlighted in a different colour }\end{array}$ & 27 \\
\hline $\begin{array}{l}\text { Transition matrix to indicate the expected } \\
\text { percentages of pupils attaining levels at the } \\
\text { end of one Key Stage compared to the } \\
\text { previous Key Stage }\end{array}$ & $\begin{array}{l}\text { Tabular form, highlighted to } \\
\text { show typical expected positive } \\
\text { progress }\end{array}$ & 18 \\
\hline $\begin{array}{l}\text { Table showing percentages of pupils } \\
\text { needing to attain levels of examination } \\
\text { results to meet inspection standards, } \\
\text { according to school grouping and levels of } \\
\text { free school meals }\end{array}$ & $\begin{array}{l}\text { Tabular form, with a column } \\
\text { highlighted in another colour }\end{array}$ & 16 \\
\hline $\begin{array}{l}\text { Comparison of predicted outcomes against } \\
\text { prior results, with actual outcomes against } \\
\text { prior results }\end{array}$ & $\begin{array}{l}\text { Tabular form, with actual and } \\
\text { predicted numbers shown in } \\
\text { different colours }\end{array}$ & 25 \\
\hline $\begin{array}{l}\text { Pupil performance recorded by registration } \\
\text { group, gender, ethnicity, end of Key Stage } \\
2 \text { results in science, end of year results in } \\
\text { science, and calculated added value }\end{array}$ & $\begin{array}{l}\text { Tabular form, with colour } \\
\text { highlighting showing below and } \\
\text { above expected achievement, } \\
\text { and below and above added } \\
\text { value measures }\end{array}$ & 11 \\
\hline $\begin{array}{l}\text { Pupil performance recorded by registration } \\
\text { group, date of birth, gender, ethnicity, } \\
\text { teacher assessments in geography, CAT }\end{array}$ & $\begin{array}{l}\text { Tabular form, with colour } \\
\text { highlighting showing below and } \\
\text { above expected achievement }\end{array}$ & 11 \\
\hline
\end{tabular}




\begin{tabular}{|c|c|c|}
\hline results, and reading ages & & \\
\hline $\begin{array}{l}\text { Numbers of pupils estimated to attain at } \\
\text { each level in English based on comparisons } \\
\text { of results of the CATs verbal and non- } \\
\text { verbal reasoning tests }\end{array}$ & $\begin{array}{l}\text { Tabular form, with colour } \\
\text { highlighting showing numbers } \\
\text { estimated to attain by only one } \\
\text { rather than both test results }\end{array}$ & 12 \\
\hline $\begin{array}{l}\text { Comparison of schools' results by } \\
\text { achievement levels by gender }\end{array}$ & $\begin{array}{l}\text { Tabular form, with extremes } \\
\text { highlighted in another colour }\end{array}$ & 27 \\
\hline $\begin{array}{l}\text { Table of subject residuals comparing } \\
\text { school with local authority and national } \\
\text { figures }\end{array}$ & $\begin{array}{l}\text { Tabular form, with one subject } \\
\text { residual highlighted in another } \\
\text { colour }\end{array}$ & 23 \\
\hline $\begin{array}{l}\text { Differences between levels of attainment } \\
\text { given as probabilities, based on prior } \\
\text { results, on school grouping, and compared } \\
\text { to actual results }\end{array}$ & $\begin{array}{l}\text { Tabular form, with significant } \\
\text { differences from expectations } \\
\text { highlighted }\end{array}$ & 36 \\
\hline $\begin{array}{l}\text { Pupil performance recorded by registration } \\
\text { group, gender, ethnicity, end of Key Stage } \\
2 \text { and } 3 \text { results, reading ages, and } \\
\text { standardised yearly tests }\end{array}$ & $\begin{array}{l}\text { Tabular form, without } \\
\text { highlighting }\end{array}$ & 10 \\
\hline $\begin{array}{l}\text { Estimated probabilities of pupils attaining } \\
\text { levels of examination outcomes based on } \\
\text { prior accrued results }\end{array}$ & $\begin{array}{l}\text { Tabular form, without } \\
\text { highlighting }\end{array}$ & 16 \\
\hline $\begin{array}{l}\text { Spreadsheet to calculate numbers of pupils } \\
\text { in a school estimated to attain levels of } \\
\text { examination outcomes based on prior } \\
\text { accrued results }\end{array}$ & $\begin{array}{l}\text { Tabular form, without } \\
\text { highlighting }\end{array}$ & 16 \\
\hline $\begin{array}{l}\text { Table of point scores to indicate how } \\
\text { 'solid' a level a pupil has attained }\end{array}$ & $\begin{array}{l}\text { Tabular form, without } \\
\text { highlighting }\end{array}$ & 18 \\
\hline $\begin{array}{l}\text { Table to allow schools to plot their pupil } \\
\text { results to compare with a national } \\
\text { transition matrix to indicate the expected } \\
\text { percentages of pupils attaining levels at the } \\
\text { end of one Key Stage compared to the } \\
\text { previous Key Stage }\end{array}$ & $\begin{array}{l}\text { Tabular form, without } \\
\text { highlighting }\end{array}$ & 18 \\
\hline $\begin{array}{l}\text { Table showing measures of typical yearly } \\
\text { progress for different groups of pupils }\end{array}$ & $\begin{array}{l}\text { Tabular form, without } \\
\text { highlighting }\end{array}$ & 19 \\
\hline $\begin{array}{l}\text { Plotting pupils estimated to achieve subject } \\
\text { results at the end of a Key Stage by class } \\
\text { group }\end{array}$ & $\begin{array}{l}\text { Tabular form, without } \\
\text { highlighting }\end{array}$ & 26 \\
\hline $\begin{array}{l}\text { Comparison of national achievement levels } \\
\text { by gender }\end{array}$ & $\begin{array}{l}\text { Tabular form, without } \\
\text { highlighting }\end{array}$ & 27 \\
\hline $\begin{array}{l}\text { Comparison of school results by } \\
\text { achievement levels by term of birth }\end{array}$ & $\begin{array}{l}\text { Tabular form, without } \\
\text { highlighting }\end{array}$ & 28 \\
\hline $\begin{array}{l}\text { Estimates of attainment given as } \\
\text { probabilities, based on prior results, and on } \\
\text { school grouping }\end{array}$ & $\begin{array}{l}\text { Tabular form, without } \\
\text { highlighting }\end{array}$ & 35 \\
\hline
\end{tabular}

It is clear from this list that different forms and types of visualisation were used (line graphs, column graphs, and tables). Different features were applied to these different forms of visualisation. The range of different features are identified, grouped and shown in Table 2. 
Table 2: Visual forms and highlighting techniques shown within an advisory document (DfES, 2002)

\begin{tabular}{|c|c|}
\hline Graphical or tabular form of visual item & Frequency \\
\hline \multicolumn{2}{|l|}{ Line graphs } \\
\hline Graphical form, showing a single line & 1 \\
\hline $\begin{array}{l}\text { Graphical form, showing a single line with pupils with low estimated added value } \\
\text { being highlighted in a different colour }\end{array}$ & 1 \\
\hline Graphical form, showing lines in different colours & 3 \\
\hline $\begin{array}{l}\text { Graphical form, with median and quartile lines in different colours, and pupils with } \\
\text { different extents of added value highlighted in different colours }\end{array}$ & 1 \\
\hline \multicolumn{2}{|l|}{ Column graphs } \\
\hline Graphical form, with columns shown in a colour & 3 \\
\hline Graphical form, showing colour and column height comparisons & 5 \\
\hline \multicolumn{2}{|l|}{ Tables } \\
\hline Tabular form, without highlighting & 10 \\
\hline Tabular form, with some figures, cells or columns highlighted & 8 \\
\hline Tabular form, with significant differences from expectations highlighted & 1 \\
\hline
\end{tabular}

Within the entire document, there were 33 items that were shown in visual form. Of these, 6 were in line graph form, 8 in column graph form, and 19 were in tabular form. Of the 7 line graphs, 6 used forms of colour highlighting to indicate particular features. Of the 8 column graphs, all used colour to highlight columns and, where appropriate, comparisons between columns. Of the 19 tables, 9 used some forms of highlighting (usually colouring of numbers or different forms of background colouring). However, only one of these items (from a research charity source) used colour to indicate statistically significant differences.

Some indication of the shift over time, in terms of visual forms used, can be gained by looking at the types of visual presentations highlighted by a school MIS provider, when showing features of its curriculum facilities to a teacher group. The visual forms shown in the presentation (Sherwood, 2008) are grouped using the same categories as those in Table 2 above, and the results are shown in Table 3.

Table 3: Visual forms and highlighting techniques shown within a presentation of a school MIS (Sherwood, 2008)

\begin{tabular}{|c|c|}
\hline Graphical or tabular form of visual item & Frequency \\
\hline \multicolumn{2}{|l|}{ Line graphs } \\
\hline Graphical form, showing a single line & 0 \\
\hline $\begin{array}{l}\text { Graphical form, showing a single line with pupils with low estimated added value } \\
\text { being highlighted in a different colour }\end{array}$ & 0 \\
\hline Graphical form, showing lines in different colours & 1 \\
\hline $\begin{array}{l}\text { Graphical form, with median and quartile lines in different colours, and pupils with } \\
\text { different extents of added value highlighted in different colours }\end{array}$ & 0 \\
\hline $\begin{array}{l}\text { Graphical form, with median and quartile lines in different colours, and densities of } \\
\text { pupils with different extents of added value highlighted by size }\end{array}$ & 5 \\
\hline Graphical form, in star form showing a coloured line & 1 \\
\hline \multicolumn{2}{|l|}{ Column graphs } \\
\hline Graphical form, with columns shown in a colour & 2 \\
\hline Graphical form, showing colour and column height comparisons & 4 \\
\hline \multicolumn{2}{|l|}{ Tables } \\
\hline Tabular form, without highlighting & 15 \\
\hline Tabular form, with some figures, cells or columns highlighted & 6 \\
\hline Tabular form, with significant differences from expectations highlighted & 0 \\
\hline
\end{tabular}


Within the entire presentation, there were 34 items that were shown in visual form (about the same number as those within the advisory document). Of these, 7 were in line graph form, 6 in column graph form, and 21 were in tabular form (again, roughly the same balance within the advisory document). Of the 7 line graphs, all used forms of colour highlighting to indicate particular features. However, 6 of these line graphs used new forms of presentation (one was in the form of a star graph, and five were in the form of trend graphs that showed densities of pupil responses by the differential size of coloured dots). Of the 6 column graphs, all used colour to highlight columns and comparisons between columns. Of the 21 tables, 6 used some forms of highlighting, but none of these items used colour to indicate statistically significant differences (although it is true to say that the MIS did provide access to tools that offered these forms of visualisation). The visual forms in this presentation indicated that colour highlighting was used prominently in line and column graph forms, that new forms of line graphs had been deployed, but that statistically significant differences were not shown within these presentations.

Other sources (such as the Data Enabler Toolkit from the Specialist Schools and Academies Trust, 2008) also provide access to new forms of presentation. In this resource, Venn diagrams are now used to show numbers of pupils attaining numbers of pass grades in Key Stage 4 tests (GCSE grade levels $A^{*}$ to $C$ ), and elements of the diagram give an overview of numbers of students gaining one, two, three or more, four or more, or five or more passes. The Venn diagram enables teachers to easily see not only the numbers from across an entire year group who are attaining certain grades, but those subjects limiting the overall number of five or more passes, as well as a facility to show the name of each student when the cursor is placed over an individual 'dot'. Considerations of statistical validity and relevance are also included within resources in the Data Enabler Toolkit: value added measures are shown in terms of current attainment levels compared to previous school attainment levels (allowing comparisons across schools to be identified); and different forms of estimated likely outcomes allow a triangulation of comparison to be made.

Using evidence about visual forms from across these sources, what can be concluded about the development of features of visual forms? A review, focused through questions raised by Visscher features, is shown in Table 4. 
Table 4: The status of visual forms with regard to Visscher features

\begin{tabular}{|c|c|}
\hline $\begin{array}{l}\text { Feature concerned } \\
\text { with visualisation }\end{array}$ & Comments about features observed in sources \\
\hline $\begin{array}{l}\text { Does visualisation } \\
\text { indicate anything } \\
\text { about information } \\
\text { validity or } \\
\text { reliability? }\end{array}$ & $\begin{array}{l}\text { Resources do tend to use a range of different techniques, and } \\
\text { many resources do indicate ways that different techniques might } \\
\text { be used to display data for specific purposes (such as } \\
\text { comparisons with previous pupil performance, or performance of } \\
\text { other schools). However, aspects concerned with validity and } \\
\text { reliability relating to individual visual forms tend not to be } \\
\text { completely obvious. It is not always clear when it is appropriate } \\
\text { and not appropriate to use a particular form, and indeed evidence } \\
\text { suggests that some schools select visual forms that represent } \\
\text { positive pictures rather than pictures to determine action. The } \\
\text { validity of using visualisations to compare school data with } \\
\text { national data, for example, is not generally discussed or } \\
\text { considered on the visualisation itself. However, there is a greater } \\
\text { tendency now to group schools so that comparing like-for-like } \\
\text { (contextual value added, for example) becomes more possible. } \\
\text { Reliability is also being considered to greater extents through the } \\
\text { use of different forms of contextual value added measures, and } \\
\text { the use of comparisons across different statistical techniques. For } \\
\text { example, the Specialist Schools and Academies Trust (SSAT, } \\
\text { 2008) now provide the comparison of estimated likely outcomes } \\
\text { using three different statistical techniques. Reliability is also } \\
\text { considered more inherently in those visualisations where } \\
\text { probabilities are indicated (in Fischer Family Trust visualisations, } \\
\text { exemplified within the DfES report, 2002, for example), or where } \\
\text { quartile lines are shown as well as median lines. }\end{array}$ \\
\hline $\begin{array}{l}\text { Does visualisation } \\
\text { indicate anything } \\
\text { about how up-to-date } \\
\text { the information is? }\end{array}$ & $\begin{array}{l}\text { Generally, the ability to access visual forms that are up-to-date is } \\
\text { becoming easier. It is possible through the school MIS that has } \\
\text { been reviewed, for example, to link to different data sources } \\
\text { (Sherwood, 2008), and to have access to visual presentations on } \\
\text { up-to-date data (as MISs often update on at least a daily basis). } \\
\text { Visual forms are usually date stamped, and this shows clearly the } \\
\text { day that the data were presented. }\end{array}$ \\
\hline $\begin{array}{l}\text { Is anything shown } \\
\text { regarding data } \\
\text { relevance? }\end{array}$ & $\begin{array}{l}\text { Relevance is an aspect that tends to be determined to an extent by } \\
\text { government department requirements. Although schools do have } \\
\text { some scope for selecting forms of presentation, there are some } \\
\text { forms that are regularly used by the government department and } \\
\text { school inspectorate. The clear labelling of visual forms does tend } \\
\text { to show how presentational forms relate to particular curriculum } \\
\text { needs (for example, an estimated likely outcome, or a potential } \\
\text { future target). }\end{array}$ \\
\hline $\begin{array}{l}\text { Are there indicators } \\
\text { of relative and } \\
\text { absolute school } \\
\text { performance? }\end{array}$ & $\begin{array}{l}\text { These indicators have been built into a range of systems since at } \\
\text { least 2002. It has been possible for schools to compare their } \\
\text { performances relative to national attainment and to their previous } \\
\text { attainment. More recently, the Fischer Family Trust (Treadaway, } \\
\text { 2008) has made available the facility for schools to work in } \\
\text { groups or federations, to compare their data and performance, to } \\
\text { share their strengths and support their weaknesses. }\end{array}$ \\
\hline $\begin{array}{l}\text { Does visualisation } \\
\text { show trends, } \\
\text { relationships and } \\
\text { differences over } \\
\text { time? }\end{array}$ & $\begin{array}{l}\text { These aspects have been accessible since at least } 2002 \text {. Trends at } \\
\text { pupil, class, subject, school, local authority and national level } \\
\text { have been made available. Relationships and differences over } \\
\text { time have also been shown through a range of visual forms (see } \\
\text { Table } 1 \text { above). }\end{array}$ \\
\hline $\begin{array}{l}\text { Does it present } \\
\text { standard and tailored } \\
\text { information? }\end{array}$ & $\begin{array}{l}\text { Increasingly, school MISs allow tailored information to be } \\
\text { presented as well as standard information (Sherwood, 2008). The } \\
\text { SIMS MIS now allows schools to link to other sources of data }\end{array}$ \\
\hline
\end{tabular}




\begin{tabular}{|c|c|}
\hline & $\begin{array}{l}\text { (such as that from the government department, the Fischer Family } \\
\text { Trust, and research test sources), and allows schools to enter their } \\
\text { own data in fields that can then be analysed through a wide range } \\
\text { of selected techniques. }\end{array}$ \\
\hline $\begin{array}{l}\text { Is presentation } \\
\text { offered in accessible } \\
\text { and appealing forms? }\end{array}$ & $\begin{array}{l}\text { Increasingly, visual forms are using features to highlight } \\
\text { exceptions or differences, and are using techniques that indicate } \\
\text { features such as density, strengths and weaknesses. Teachers are } \\
\text { voicing fewer concerns about accessibility and appeal of visual } \\
\text { presentations, and are now voicing more concerns about aspects } \\
\text { such as relevance and validity. }\end{array}$ \\
\hline $\begin{array}{l}\text { Is support offered in } \\
\text { using data correctly? }\end{array}$ & $\begin{array}{l}\text { Data support is available to schools. Local authorities continue to } \\
\text { support through courses and help desks, as do national support } \\
\text { agencies such as SSAT (2008). There is now a desire to engage } \\
\text { with researchers more on aspects of data use. For example, this } \\
\text { year a research practitioner course on data handling has been run } \\
\text { for the first time (SSAT, 2008), although this course has not } \\
\text { focused specifically on visual forms of presentation. }\end{array}$ \\
\hline $\begin{array}{l}\text { Are time and effort } \\
\text { requirements } \\
\text { considered? }\end{array}$ & $\begin{array}{l}\text { Schools generally provide access to development time for staff, } \\
\text { and some schools are now focusing much more on support for } \\
\text { teachers in data handling. Visual forms of presentation have not } \\
\text { been a specific focus, but some schools recognise that online } \\
\text { forms of visual presentation of data are positively affecting effort } \\
\text { and time. }\end{array}$ \\
\hline $\begin{array}{l}\text { How are issues of } \\
\text { complexity and } \\
\text { clarity addressed? }\end{array}$ & $\begin{array}{l}\text { Clarity is being addressed increasingly through the auspicious use } \\
\text { of visual forms of presentation. Increased clarity is also allowing } \\
\text { levels of complexity to be addressed to increasing extents. For } \\
\text { example, in trend graphs, densities of pupil performance are now } \\
\text { being shown by sizes of dots (Sherwood, 2008), allowing a } \\
\text { different level of complexity to be highlighted in a recognisable } \\
\text { form. }\end{array}$ \\
\hline $\begin{array}{l}\text { How is user support } \\
\text { in solving problems } \\
\text { addressed? }\end{array}$ & $\begin{array}{l}\text { User support is being enhanced increasingly over time with } \\
\text { regard to data handling. Increasing numbers of practitioners with } \\
\text { wider understanding and knowledge are being trained, and are } \\
\text { supporting others. However, with regard to support at the point of } \\
\text { use of visual forms, this is not necessarily built into data handling } \\
\text { systems, although systems allow visual forms to be regenerated } \\
\text { or saved easily, so that users feel more able to engage with others } \\
\text { about any issues they identify. }\end{array}$ \\
\hline
\end{tabular}

\section{DIRECTIONS AND POLICIES}

It is clear from the responses in Table 4 that some features of visual forms of data presentation have been addressed to greater extents than have others in terms of an evolution over time. The features that have been addressed more successfully at this point in time are:

- Visualisation often indicates how up-to-date the information is.

- Relevance is often indicated on the labels on presentations of data presented visually.

- Indicators of relative and absolute school performance are accessible and different forms of comparison are widening. 
- Visualisation is used to show trends, relationships and differences in a range of ways.

- Standard and tailored information is increasingly accessible.

- Presentation is increasingly offered in accessible and appealing forms.

- Issues of complexity and clarity are being increasingly addressed.

There are features that have not been addressed so successfully, and that should clearly be a focus for future direction and policies (especially for those concerned with the increasing development and uses of visual forms). The features that are worthy of more focus at this time are:

- Visualisation needs to indicate much more information about specific validity and reliability.

- Support needs should focus more on how to use data 'correctly'.

- Time and effort requirements need to be considered when visualisation forms are developed.

- Offering user support in solving problems through appropriate visual forms needs more focus.

The need to focus on these features is becoming increasingly recognised. For example, Treadaway (2008), in a presentation to a conference focusing on school achievement, indicated that more attention should be given to discussion of findings from data (such as the selection of pupil targets from background and estimated future attainment) with pupils, rather than using data to merely take actions. He was pointing to the need for visualisations to be 'smarter', and to indicate points of concern and need, as well as to offer raw data views. Data (particularly statistical data) have perhaps (too) frequently been offered in forms that have assumed that the reader or user is a 'smart' interpreter. Evidence suggests that this can happen, but that it may not happen. Sutherland (1992) pointed out the many ways that data can be used irrationally, or how its uses can lead to irrational views or actions. Can it be assumed that educational users are any different from other users in this respect? The evidence suggests not. However, indicators suggest that the recognition by teachers and managers in schools of the need to be 'smarter' with regard to data handling is in itself a useful and positive trend. There is a clearly a great deal of potential application for a range of focused research in this field.

\section{REFERENCES}

Australian Bureau of Statistics (2007). 1211.0.55.001 - Research Paper: Data Visualisation. Retrieved August 15, 2008, from http://www. abs.gov.au/AUSSTATS/abs@.nsf/Latestproducts/1211.0.55.001Main\%2 0Features $1 \mathrm{Jul} \% 202007$ ? opendocument $\&$ tabname $=$ Summary $\&$ prodno $=$ 1211.0.55.001\&issue $=\mathrm{Jul} \% 202007 \&$ num $=\&$ view $=$

Department for Education and Skills. (2002) Releasing Potential, Raising Attainment: Managing Data in Secondary Schools. DfES: London 
Fischer Family Trust. (n.d.). Data Analysis Project. Retrieved July 13, 2007, from http://www.fischertrust.org/

Fitz-Gibbon, C.T. (2002). A Typology of Indicators. In A.J. Visscher and R. Coe (Eds.) School improvement through performance feedback. Routledge: Oxford and New York.

Gray, J. (2002). Jolts and Reactions: Two Decades of Feeding Back Information on Schools' Performance. In A.J. Visscher and R. Coe (Eds.) School improvement through performance feedback. Routledge: Oxford and New York.

Kirkup, C., Sizmur, J., Sturman, L. and Lewis, K. (2005) Research Report No 671: Schools' Use of Data in Teaching and Learning. Department for Education and Skills: Nottingham

Passey, D. (2002). Schools in Exceptionally Challenging Circumstances: ICT Audit. Lancaster University: Lancaster

Sherwood, C. (2008). Assessment Manager 7, Performance Analysis 7. Presentation given at the Second Conference of the Research Practitioner Course in Data Management, Aston University Business School, 30 April 2008

Specialist Schools and Academies Trust. (2007). Toolkits. Retrieved July 13, 2007, from https://secure.ssatrust.org.uk/eshop/default.aspx?mcid= $22 \& \operatorname{scid}=34 \&$ productid $=627$

Smart Centre (2007). Smart Centre Durham University. Retrieved August 15, 2008, from http:/www.dur.ac.uk/smart.centre/

Specialist Schools and Academies Trust. (2008). Data Enabler. Retrieved July 12, 2008, from www.ssatrust.org.uk/dataenabler

Sutherland, S. (1992). Irrationality: The Enemy Within. Constable: London.

Treadaway, M. (2008). Data visualisation. Presentation given at the Specialist Schools and Academies Trust Achievement Show, Emirates Stadium London, 17 June 2008

Tufte, E.R. (1990). Envisioning information. Graphics Press: Cheshire, CT.

Visscher, A.J. (2002). A Framework for Studying School Performance Feedback Systems. In A.J. Visscher and R. Coe (Eds.) School improvement through performance feedback. Routledge: Oxford and New York. 